\title{
NOVAS FORMAS DE PODER E CONTROLE NAS ORGANIZAÇÕES
}

\author{
Por Ana Paula Paes de Paula \\ Professora da UFMG \\ E-mail: appaula@face.ufmg.br
}

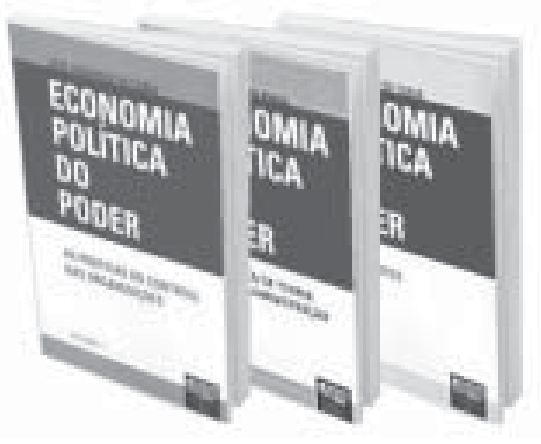

Composta por três volumes, a mais recente obra de José Henrique de Faria, Economia política do poder, é fruto de 25 anos de pesquisa e reflexão. 0 título talvez não remeta o leitor diretamente para questões da esfera dos estudos organizacionais, mas o conteúdo traz uma densa e sólida discussão sobre as relações de poder nas organizações sob uma perspectiva crítica. Inspirado pela teoria crítica frankfurtiana, o autor procura fundar uma linha de pensamento por ele denominada economia política do poder, uma concepção interdisciplinar do estudo do poder nas organizações que abrange as ciências econômicas, as ciências sociais, a história e a psicossociologia. A exemplo dos marxistas ocidentais, Faria se vale das noções de estrutura e superestrutura para avaliar como operam as instâncias manifestas (regramento eestruturas) eocultas (relações subjetivas e inconsciente individual) nas configurações de poder e controle das organizações.

\section{ECONOMIA POLIITICA DO PODER}

De José Henrique de Faria

Curitiba: Juruá Editora, 2004. v. 1 (202 p.), v. 2 (250 p.), v. 3 (192 p.).
A publicação é bem-vinda, pois são poucos os trabal hos que exploram os estudos organizacionais sob uma perspectiva marxista. $\mathrm{Na}$ atual valorização de estudos de orientação pósmoderna, o marxismo costuma ser apontado como uma grande narrativa e vem ocupando uma posição cada vez mais marginal. As perdas não poderiam ser maiores, pois juntamente com o marxismo relega-se o potencial de crítica e anál ise presente no método dialético e nas elaborações de vários autores que o professam. Dessa forma, mais do que valorizar o embate entre modernismo e pós-modernismo, os estudiosos das organizações deveriam optar por uma posição mais heterodoxa e buscar articular as contribuições presentes nas diversas correntes de pensamento. 0 resgate de autores como Herbert Marcuse, Theodor Adorno e Walter Benjamin revela que estes anteciparam em décadas as preocupações que hoje circundam os pós-modernos, apontan- do caminhos para começar um diálogo entre as diversas vertentes.

Os volumes que compõem a obra de José H enrique Faria podem ser tomados separadamente, mas somente a leitura completa trará ao leitor a verdadeira dimensão do trabalho realizado pelo autor. No primeiro volume, identificado pelo subtítulo "Fundamentos", Faria procura delinear as bases epistemológicas e teóricas da economia política do poder, explorando 0 arcabouço que circunda o poder e o controle nas organizações sociais, por meio da discussão de questões que sustentam o pensamento marxista, tais como a organização e a divisão do trabalho, a exploração do trabalho, os processos de trabalho e de valorização, o processo de acumulação de capital e as tecnologias físicas e de gestão. Em seguida, Faria faz uso da dialética para discutir o contexto político e sócio-histórico no qual as relações no mundo contemporâneo se desdobram. 0 autor resgata os con- 
ceitos de classe social, elites e oligarquia em uma tentativa de atual izá-los e consolidá-los à luz das novas realidades sociais. Outro capítulo é dedicado à análise dos conceitos de poder e de suas relações, destacando-se pela síntese e profundidade al cançadas pelo autor. Finalizando esse volume, Faria explora o paradoxo existente entre a práxis e o discurso nas organizações, realizando uma discussão sobre responsabilidade social e democracia que revela como as organizações estão reelaborando o controle social por meio do discurso da ética corporativa.

No segundo volume, intitulado "U ma Crítica da Teoria Geral da Administração", o autor se dedica a criticar a ideologia que perpassa as elaborações teóricas da área, que são definidoras das formas, processos e mecanismos de controle nas organizações. A inspiração buscada em seu mestre Maurício Tragtenberg é evidente, por ter elaborações similares que constam no livro Burocracia eideologia (São Paulo: Ática, 1974) . 0 trabalho de Faria procura seguir o mesmo caminho, mas amplia o escopo, havendo capítulos intei ros dedicados aos enfoques da teoria administrativa (organização científica do trabalho, relações humanas, neoclassicismo, behaviorismo, estruturalismo, funcionalismo, teoria Z, círculos de controle da qualidade e produção flexível). Percorrendo esses capítulos, o leitor tem uma opção de contraponto aos conhecidos manuais descritivoprescritivos de teoria geral da administração. De um modo geral, os capítulos são instigantes no que se refere à abordagem, mas não esgotam totalmente as discussões l evantadas, deixando o leitor à espera de um maior aprofundamento. No entanto, justamente por isso geram a impressão de que há muitos aspectos inexplorados nas teorias da administração no que diz respeito à perspectiva crítica, abrindo caminhos para futuros pesquisadores interessados em aprofundar as análises e validar as críticas realizadas. Finalizando o volume, Faria realiza uma análise da transição do taylorismo-fordismo para a gestão flexível, por meio de um estudo de caso que aborda o seu impacto nas organizações e nas relações de trabal ho, destacando os novos mecanismos de opressão, controle e sofrimento impostos aos trabal hadores.

No terceiro volume, "As Práticas do Controle nas Organizações", Faria aprofunda a questão abordada acima, tomando como referência um conjunto de pesquisas empíricas sobre processos objetivos e subjetivos de controle que emergem nas unidades produtivas. No primeiro capítulo, 0 autor resgata as seteinstâncias de análise das organizações (mítica, sócio-histórica, institucional, organizacional, grupal, individual e pulsional) apresentadas por Eugène Enriquez em seu livro $A$ organização em análise (Petrópolis: Vozes, 1997), explorando-as em detaIhe a partir da perspectiva do controle. Conclui que a investigação dos mecanismos de controle deve contemplar a estrutura organizacional, os conflitos, a identidade e o envolvimento com o trabalho. No capítulo seguinte, Faria propõe uma teoria crítica do controle nas organizações. Primeiro, 0 autor mapeia os mecanismos típicos de controle articulados em cada uma das teorias de administração analisadas no segundo volume. Em seguida, Faria discute, de uma perspectiva teórica, os níveis de controle - econômico, político-ideológico e psicossocial -, apontando as formas de controle manifestas em cada um deles. Para final izar, el e apresenta uma matriz que cruza essas formas de controle com as instâncias de análise das organizações discutidas por Enriquez, apresentando separadamente os controles objetivos e subjetivos que emergem em cada uma dessas instâncias. As sete matrizes geradas constituem um modelo referencial teórico-analítico valioso para qualquer pesquisador que esteja interessado na questão do poder e do controle nas organizações. 0 autor encerra o capítulo discutindo a questão das alternativas para a gestão autocrática, como coletivos e cooperativas que pregam a mínima divisão vertical de trabalho, a autonomia, a responsabilidade, a democracia e o equilíbrio ecológico. Resgata também o ideal de alguns movimentos populares democráticos, cujo funcionamento se inspira na autogestão, ou seja, em um sistema de paridade com completa participação nas decisões sobre 0 trabal ho e a gestão. Com essa nova referência implícita ao pensamento de Maurício Tragtenberg, Faria abre espaço para suas considerações finais, que no melhor estilo marxista discutem a nova crise estrutural do capital e apontam a importância, nesse contexto, de uma teoria crítica do controle sobre o processo de trabal ho.

Neste último volume, o leitor sente falta de um detalhamento das pesquisas empíricas que serviram de suporte para a elaboração teórica apresentada, pois estas poderiam fornecer algumas bases metodológicas e analíticas queauxiliariam o pesquisador na reprodução de investigações da mesma natureza. Por outro lado, como o nível de controle psicossocial costuma ser relegado pelos pesquisadores devido às dificuldades intrínsecas de análise, suas formas de controle poderiam ter sido mais aprofundadas e exemplificadas. Mas 0 texto de Faria é uma publicação de fôlego a exigir dedicação do leitor, que será plenamente recompensado pelo seu esforço, pois se trata de uma leitura indispensável para todos aqueles que se ocupam dos estudos sobre poder e controle nas organizações e tende a se tornar um clássico da teoria organizacional brasileira. 